Prevalence of obesity among

Bangladeshi pregnant women at their first trimester of pregnancy

\title{
Shatabdi Goon
}

Nutrition and Food Engineering Department, Daffodil International University, Dhanmondi, Dhaka, Bangladesh

Vol. 2, No. 2 (2013) | ISSN 2166-7403 (online)

DOI 10.5195/cajgh.2013.70 | http://cajgh.pitt.edu

\section{(c) $)$ EY}

New articles in this journal are licensed under a Creative Commons Attribution 3.0 United States License.

\section{ULLS D-Sork}

This journal is published by the University Library System of the University of Pittsburgh as part of its D-Scribe Digital Publishing Program and is cosponsored by the University of Pittsburgh Press. 


\section{Abstract}

BACKGROUND: Paradoxically, the escalating global epidemic of maternal obesity coexists with malnutrion in many areas of Bangladesh. This proves a major challenge to obstetric practice from preconception to postpartum due to related comorbid conditions including: maternal death or severe morbidity, gestational diabetes and hypertension, increased risk of early and recurrent miscarriage, pre-eclampsia, thromboembolism, post-caesarean wound infection, postpartum haemorrhage, and low breastfeeding rates. A dramatic increase in birth defects and other pregnancy-induced disorders related to maternal obesity has added millions of dollars to health care costs leading great economical loss to the country.

OBJECTIVE: The study was designed to determine the prevalence of obesity among Bangladeshi pregnant women in their $1^{\text {st }}$ trimester of pregnancy.

STUDY DESIGN: 426 pregnant women presenting to the antenatal care until of Azimpur maternity hospital of Dhaka, Bangladesh were randomly selected for this cross sectional study to determine their weight status using body mass index (BMI, $\mathrm{kg} / \mathrm{m}^{2}$ ).

RESULT: 90 (21.2\%) pregnant women were reported as obese with pregnancy BMI of $>30 \mathrm{~kg} / \mathrm{m}^{2} .171(40.1 \%)$ and $140(32.8 \%)$ pregnant women were reported as overweight and healthy with pregnancy BMI of $25-29.9 \mathrm{~kg} / \mathrm{m}^{2}$ and $18.5-24.9 \mathrm{~kg} / \mathrm{m}{ }^{2}$, respectively. Statistical analysis revealed obesity and overweight status were found to be significantly associated with age; women aged 31 or above were more likely to be obese $(\mathrm{OR}=2.5$; 95\% CI 1.53-3.96) and overweight $(\mathrm{OR}=3.3$; 95\% CI 2.154.99).

CONCLUSION: This study provides evidence of increasing trends in obesity among Bangladeshi pregnant women, which poses possible health risks both for mother and child. The findings of this study may act as baseline data for monitoring the effectiveness of national programs for the prevention and control of maternal obesity.

Keywords: obese pregnant, first trimester, adverse pregnancy outcome, body mass index, neonatal health, maternal health

Prevalence of obesity among Bangladeshi pregnant women at their first trimester of pregnancy

\section{Shatabdi Goon}

\section{Nutrition and Food Engineering Department, Daffodil International University, Dhanmondi, Dhaka, Bangladesh}

\section{Research}

Maternal obesity and related comorbid conditions have serious impact on the health and development of obese women's offspring. The incidence of maternal obesity at the start of pregnancy is increasing worldwide. ${ }^{1}$ International studies show a prevalence of maternal obesity ranging from $1.8 \%$ to $25.3 \%$ across countries. ${ }^{2}$ Approximately $50 \%$ of pregnant women have a body mass index (BMI) $>25$ $\mathrm{kg} / \mathrm{m}^{2,3}$ Nearly two-thirds of reproductive-age women in the United States (U.S.) are currently overweight or obese, placing them at elevated risk for adverse health outcomes. ${ }^{4}$ The recent National Health and Nutrition Examination Survey (NHANES) found that in the United States, more than $50 \%$ of pregnant women are overweight or obese and $8 \%$ of reproductive-aged women are extremely obese. ${ }^{5}$ In $2009,26 \%$ of adult,

This work is licensed under a Creative Commons Attribution 3.0 United States License.

This journal is published by the University Library System of the University of Pittsburgh as part of its D-Scribe Digital Publishing Program and is cosponsored by the University of Pittsburgh Press. 
reproductive-age, U.S. women were classified with a $\mathrm{BMI} \geq 30 \mathrm{~kg} / \mathrm{m}^{2}$.

Compared to developed countries, maternal obesity is less of an epidemic in developing ones; however, Bangladeshi women of reproductive age have shown a trend of increasing BMI. ${ }^{7}$ A survey conducted among this subpopulation found obesity prevalence increased from $2.7 \%$ to $8.9 \%$ between 1996 and 2006 . $^{7}$ In comparison, the prevalence of maternal obesity in the United States ranged from $13.9 \%$ to $25.1 \%$ between 2004 and 2005. ${ }^{8}$ Current Institute of Medicine guidelines, published in 1990, recommend that all women can expect to gain one or two kilograms in their first trimester of pregnancy, but additional weight gain above is considered excessive. ${ }^{9}$ In recent years, excessive weight gain has led to increased obesity prevalence among pregnant women, resulting in maternal and fetal health complications. Maternal obesity carries significant risks for the mother and fetus with increased health risks to the mother during the antenatal, intrapartum, and postnatal periods. ${ }^{10-13}$ Excess accumulation of adipose tissue within the abdominal cavity, or visceral obesity, among obese, pregnant women has been associated with a cluster of metabolic alterations, which includes: insulin resistance, hyperinsulinemia, elevated triglyceride levels, low HDL cholesterol, and hypertension. ${ }^{14,15}$ Evidence from both animal and human studies indicates that maternal obesity 1) increases the risk for offspring to develop obesity, 2) alters body composition in child- and adulthood, and 3) impacts the offspring's cardiometabolic health with dysregulation of metabolism, including: insulin homoeostasis, development of hypertension, and vascular dysfunction. ${ }^{16}$

Maternal obesity is associated with increased odds of neural tube defects, ${ }^{17-22}$ spina bifida, ${ }^{17}$ cardiovascular anomalies, ${ }^{23}$ and high mortality rate. Reynolds et al. found that offspring of obese mothers have an increased risk of hospital admission for a cardiovascular event $(\mathrm{OR}=1.29 ; 95 \%$ CI $1.06-1.57)$ compared with offspring of mothers with normal BMI. ${ }^{24}$ First trimester maternal obesity has significantly increased over time, having more than doubled from $7.6 \%$ to $15.6 \%$ since $1994,{ }^{25}$ resulting in lost pregancies and birth defects ${ }^{26}$ that occur during embryogenesis. Overweight and obese women have larger anatomic depots of adipose tissue in all compartments, resulting in different metabolic adaptations. ${ }^{27}$ Obese women are more likely to develop gestational diabetes, ${ }^{28,29}$ high blood pressure, ${ }^{30-33}$ and proteinuria ${ }^{34-37}$ after 20 weeks of pregnancy, which promote preeclampsia. ${ }^{38,39}$ Compared with normal weight women (BMI $<25 \mathrm{~kg} / \mathrm{m}^{2}$ ), a recent meta-analysis of 20 studies demonstrated that the OR of developing gestational diabetes was 2.14 (95\% CI 1.822.53), 3.56 (95\% CI 3.05-4.21), and 8.56 (95\% CI 5.07-16.04) among overweight (BMI: $25-30 \mathrm{~kg} / \mathrm{m}^{2}$ ), obese $\left(\right.$ BMI $\left.>30 \mathrm{~kg} / \mathrm{m}^{2}\right)$, and severely obese women $\left(\right.$ BMI $\left.>40 \mathrm{~kg} / \mathrm{m}^{2}\right)$, respectively. ${ }^{29}$ Obesity among pregnant women has also been linked to poorer cognitive performance, higher incidence of autism spectrum disorders, and more attention deficithyperactivity disorder (ADHD) in their children. Increased BMI is associated with increased rates of midline vertical incision, longer operative time, urinary tract infections, ${ }^{40}$ stillbirths and fetal death, ${ }^{41-44}$ lower rates of subcuticular skin closure, ${ }^{45}$ and caesarean delivery. ${ }^{46}$ A meta-analysis of 33 studies showed that the odd ratio (OR) of cesarean delivery were $1.46(95 \%$ CI 1.34-1.60), 2.05 (95\% CI 1.86-2.27), and 2.89 (95\% CI 2.28-3.79) among overweight, obese, and severely obese women, respectively, compared with normal weight pregnant women. ${ }^{10,11,47,48}$ Also in a recent metaanalysis, a BMI $\geq 25$ was found to be associated with miscarriage, regardless of mode of conception $\left(\mathrm{OR}=1.67 ; 95 \%\right.$ CI 1.25-2.25). ${ }^{49}$ Obesity increases the risk of preterm delivery, ${ }^{50}$ (a leading cause of infant mortality, morbidity, and long-term disability). ${ }^{51}$ These risks increase with decreasing gestational age. ${ }^{52}$ Obese women are at increased risk of thrombosis as well as delivering an infant significantly larger than average (macrosomia). ${ }^{46,53,54}$

This work is licensed under a Creative Commons Attribution 3.0 United States License.

This journal is published by the University Library System of the University of Pittsburgh as part

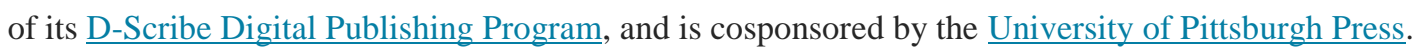


Evidence shows that a child of an obese mother may suffer from exposure to a suboptimal in utero environment and that early life adversities may extend into adulthood. ${ }^{55}$ Being obese during pregnancy might increase the risk that the baby will develop heart disease or diabetes as an adult. Research suggests that obesity during pregnancy slightly increases the risk of having a baby who's born with a birth defect, ${ }^{3}$ such as heart problems or conditions affecting the brain or spinal cord. ${ }^{19}$ Higher maternal BMI at first prenatal hospital visit is associated with increased risk of prolonged pregnancy and increased rate of induction of labor. ${ }^{56}$

Maternal obesity offers an altered genetic, hormonal, and biochemical environment for the developing fetus/embryo and influences fetal growth and organ development. ${ }^{57}$ Compared with neonates born to women of normal weight, neonates born to women with BMIs $\geq 40$ (severely obese) were at increased risk of birth injury to the peripheral nervous system, birth injury to the skeleton, respiratory distress syndrome, bacterial sepsis, convulsions, and hypoglycemia. ${ }^{58}$ Increased maternal BMI is associated with categorical and continuous reductions in the proliferative index and a continuous reduction in the apoptotic index..$^{59}$ Obese women are also less likely to initiate and sustain breastfeeding. ${ }^{60}$ Women who are obese during pregnancy might be at increased risk of a potentially serious sleep disorder in which breathing repeatedly stops and starts. Sleep apnea occurring in this group of women may further complicate anesthetic management and postoperative care. ${ }^{61}$

Helping women understand the risks associated with obesity and working with them to develop strategies to decrease their risk is a challenge for both the patient and the healthcare provider. The objective of this study was to evaluate the prevalence of maternal obesity among Bangladeshi pregnant women.

\section{Methods}

Study design
This cross-sectional study was carried out at Azimpur maternity hospital, Dhaka, Bangladesh between May and June 2013. A total of 450 urban, pregnant women in their first trimester of pregnancy were selected by systemic random process by approaching every $2^{\text {nd }}$ woman attending to prenatal care clinic. After approaching potential participants, 426 pregnant women $(94.6 \%)$ agreed to participate. 24 pregnant women refused consent. Verbal, informed consent was obtained from all study subjects per the Bangladesh Medical Research Council.

\section{Inclusion/ Exclusion Criteria}

Women were approached to participate in this investigation if they were currently in their first trimester of pregnancy and attending the prenatal care clinic of Azimpur maternity hospital. Women were exluded from analysis if they had a history of hypertension, diabetes, or spontaneous abortions. Thus, 426 pregnant women were enrolled and included in analysis.

\section{Data Collection}

Participants completed questionnaires providing information about age, month of pregnancy, and education status. Age was stratified into 4-year categories: <20 years, 21-25 years, 26-30 years, and $>30$ years.

All demographic information was collected via face-to-face interview. Body mass index (BMI) $\left(\mathrm{kg} / \mathrm{m}^{2}\right)$ was calculated based on clinically assessed weight $(\mathrm{kg})$ and height $(\mathrm{m})$ at baseline. The current analysis considered only the baseline measurements, as there was no notable change with regard to BMI during the follow up across the trials. WHO definitions were used to categorize women as normal weight (BMI: 18.524.9), overweight (BMI: 25-29.9), and obese (BMI: 30+). Substantial weight gain typically does not occur

This work is licensed under a Creative Commons Attribution 3.0 United States License.

This journal is published by the University Library System of the University of Pittsburgh as part of its D-Scribe Digital Publishing Program, and is cosponsored by the University of Pittsburgh Press. 
during the first trimester of pregnancy, therefore anthropometric measurements taken at baseline were compared to prepregnancy measurements found in the patients' medical records. No significant differences were found between the two measurements therefore no patients were excluded. Weight and height were measured by pre-defined procedure using a standard weight scale and measuring tape.

\section{Statistical analysis}

Considering an expected obesity prevalence of $50 \%$ and using a confidence level of $95 \%$ the sample size of the cross-sectional study was calculated as 450 using the following formula:

$$
\mathrm{n}=\frac{\mathrm{t}^{2} * \mathrm{p}(1-\mathrm{p})}{\mathrm{m}^{2}}
$$

Data were analyzed using IBM SPSS $^{\circledR}$ statistics version 15.0. ${ }^{62}$ Descriptive statistics were used for demographic information and Chi-squared tests were used to test significance of associations between age and BMI.

\section{Results}

This paper presents the weight status (determined by BMI) in a sample of Bangladeshi pregnant women at their first trimester of pregnancy. 426 women were interviewed and examined. The mean age of the selected pregnant women was $27.13 \pm$ 5.38(Mean \pm SD). $66(15.5 \%)$ pregnant women were $<20$ years of age, 114 (26.8\%) 21-25 years of age. 108 (25.4\%), 26-30 years of age, and $138(32.3 \%)$ were $>30$ years. $90(21.2 \%)$ and $171(40.1 \%)$ pregnant women were classified as obese or overweight with pregnancy. 140 (32.8\%) pregnant women were normal weight. Table 1 shows the distribution of this sample by age and BMI level.

Table 1. Distribution of respondents by age and BMI $\underline{\text { level. }}$

Figure one illustrates the prevalence of overweight $(40.1 \%)$ and obese $(21.2 \%)$ participants in this sample.

Figure 1: Distribution of respondents by BMI level.

Among obese women, $48.9 \%$ were aged 31 or above. Additionally, approximately $48 \%$ of overweight women were aged of 31 or above. Women aged 31 years or above were more likely to be obese $(\mathrm{OR}=2.5$ 95\% CI 1.53-3.96) and overweight (OR=3.3; 95\% CI 2.15-4.99). The correlation between age and BMI level was found to be significant, as shown in Table 2 $(p=0.01)$.

Table 2: Unadjusted OR for selected age (30 or above) by BMI category.

Obesity was detected among $21.2 \%$ of participants. Those aged 31 years or above showed significantly higher prevalence $\left(\mathrm{X}^{2}=14.18, p<0.05\right)$. Overweight was detected among $40.1 \%$ of participants and those aged 31 years or above showed significantly higher prevalence $\left(\mathrm{X}^{2}=31.58, p<0.05\right)$. Table 3 illustrates the distribution of respondents according to weight status.

Table 3: Distribution of respondents according to the presence or absence of specific weight status.

\section{Discussion}

This work is licensed under a Creative Commons Attribution 3.0 United States License.

This journal is published by the University Library System of the University of Pittsburgh as part

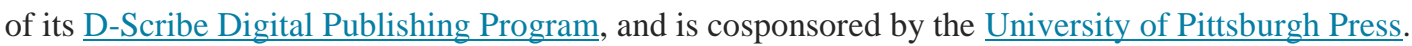


We determined the prevalence of obesity among a sample of 426 pregnant, Bangladeshi women who visited Azimpur maternity hospital in Dhaka, Bangladesh between May and June 2013. Approximately $40 \%$ of pregnant women were identified as overweight in their first trimester of pregnancy, whereas $21.2 \%$ were identified as obese. These findings mirror those of other literature. For example, Fattah et al. showed an obesity prevalence of $19 \%$ in a study of 1,000 Caucasian pregnant women. ${ }^{63}$ Another study, conducted on pregnant women receiving maternal care in Bangladesh, showed an obesity prevalence of $23 \%{ }^{64}$ Furthermore, A retrospective cohort study including 8,176 pregnant women showed an obesity prevalence of $17.7 \%,{ }^{35}$ Lastly, a cohort study of 4,830 patients with gestational diabetes (GDM) showed an obesity prevalence of $15.7 \%{ }^{65}$ Flegal et al. showed the prevalence of obesity among US women of $35.8 \%$ in 2009-2010. ${ }^{5}$ While the Centre for Maternal and Child Enquiries published that more than 1 in 20 pregnant women in US are severely obese, ${ }^{66}$ this is one of the first studies that has been conducted in Bangladesh to evaluate the current data on maternal obesity.

In most cases, Bangladeshi women are considered malnourished during their gestational period, but this study has revealed pregnant, Bangladeshi women have relatively high prevalence of overweightness and obesity. Though this study was conducted only among Bangladeshi urban women, weight status of rural pregnant women could be different considering socio-demographical condition. As a developing country, Bangladesh has struggled with the burden of malnutrition; however, these new findings of obesity prevalence among pregnant Bangladesh women point to the possibility that obesity point to the possibility of obesity becoming an increasing problem to the Bangladeshi healthcare system. Previously, pregnant, Bangladeshi women typically participated in moderate household work, but with the extension of civilization, women are becoming dependent on modern technologies to cope with their daily work needs, decreasing their amount of daily, physical activity. As a result, obesity has more prevalent among this group. Economic, technologic, and lifestyle changes have created an abundance of cheap, high-calorie food coupled with a decrease in required physical activity, promoting excessive weight gain among this group.

Research suggests that as age increases, hormonal changes and decreased physical activity increases the risk of obesity. In this study, obesity was more prevalent among women aged 31 or more. Approximately $48.9 \%$ of obesity cases were found in women aged 31 years or higher. Overweightness was also higher among women aged 31 years or higher (48\% of the sample). Other investigators showed that BMI increases with increasing maternal age. ${ }^{50}$ Our study corroborates these findings, with a positive correlation between maternal age and BMI status $(p=0.01)$. The risks of obesity in the first trimester are primarly pregnancy loss and birthday defects that occur during embryogenesis. Studies show that the risks of early miscarriage, and recurrent early miscarriage were significantly higher among obese patients. ${ }^{67}$ The evidence is fairly clear that obesity is significantly associated with increased risk of pregnancy complications, ranging from miscarriage to problems later in pregnancy. Studies in genetically identical rodents convincingly show that maternal obesity, as well as elements of a hypercaloric diet, can permanently influence offspring risk of obesity, and these findings are also supported by studies in larger mammals. ${ }^{6}$ Our findings highlight overweight and obesity as an important public health issue.

This study had several limitations. First, we only evaluated the weight status of Bangladeshi pregnant women corresponding to find out the prevalence of maternal obesity, not the maternal and fetal outcome associated with the prevalence of obesity among those pregnant women. Unless evaluating the pregnancy outcome, it will not be able to determine the overall risk associated with maternal obesity.

This work is licensed under a Creative Commons Attribution 3.0 United States License.

This journal is published by the University Library System of the University of Pittsburgh as part of its D-Scribe Digital Publishing Program, and is cosponsored by the University of Pittsburgh Press. 
Considering this issue, the next step of this study will be to follow up respondents up to their delivery, and further research should evaluate the adverse pregnancy outcome associated with the maternal obesity. Second, data other than anthropometric measurements were selfreported, and the study is cross-sectional, which does not infer causal relationships. Lastly, we examined only one maternity hospital located in Dhaka, Bangladesh, so caution should be taken to generalize the data for other maternity hospitals and locations.

\section{Conclusion}

The current study presented evidence for high rates of obesity among pregnant, Bangladeshi women in their first trimester of pregnancy. Babies born to obese mothers are more likely to be obese, develop diabetes, and have high blood pressure later in life, indicating that this issue not only affects the current generation, but may have long term implications in terms of quality of life and healthcare costs, among others. New strategies are needed to re-formulate existing obesity prevention and treatment programs by incorporating information on a healthy diet and lifestyle to produce holistic health and wellness interventions. Considering the high prevalence of obesity in females of reproductive age group in Bangladesh, this study emphasizes a strong need for pre-pregnancy advice about weight loss in these women before conception as even minimal weight loss can lead to better perinatal outcomes.

\section{References}

1. Heslehurst N, Ells L, Simpson H, Batterham A, Wilkinson J, Summerbell C. Trends in maternal obesity incidence rates, demographic predictors, and health inequalities in 36,821 women over a 15-year period. BJOG. 2007;114(2):187-194.

2. Guelinckx I, Devlieger R, Beckers K, Vansant G. Maternal obesity: Pregnancy complications, gestational weight gain and nutrition. Obes Rev. 2008;9(2):140-150.

3. Callaway L, Prins J, Chang A, McIntyre H. The prevalence and impact of overweight and obesity in an Australian obstetric population. Med J Aust. 2006;184(2):56-59.

4. Hillemeier M, Weisman C, Chuang C, Downs D, McCall-Hosenfeld J, Camacho F. Transition to overweight or obesity among women of reproductive age. $J$ Womens Health (Larchmt). 2011;20(5):703-710.

5. Flegal K, Carroll M, Kit B, Ogden C. Prevalence of obesity and trends in the distribution of body mass index among US adults, 1999-2010. JAMA. 2012;307(491-497).

6. Centers for Disease Control and Prevention. State-specific prevalence of obesity among adults - United States, 20092010.

7. Balarajan Y, Villamor E. Nationally representative surveys show recent increases in the prevalence of overweight and obesity among women of reproductive age in Bangladesh, Nepal, and India. $J$ Nutr. 2009;139(11):2139-2144.

8. Chu S, Kim S, Bish C. Prepregnancy obesity prevalence in the United States, 2004-2005. Matern Child Health J. 2009;13(5):614-620.

9. Institute of Medicine. Nutrition during pregnancy. Part I, weight gain. Washington, DC, 1990.

10. Sebire N, Jolly M, Harris J, et al. Maternal obesity and pregnancy outcome: A study of 287,213 pregnancies in London. Int $J$ Obes Relat Metab Disord. 2001;25(8):1175-1182.

11. Cedergren M. Maternal morbid obesity and the risk of adverse pregnancy outcome. Obstetrics and gynecology. 2004;103(2):219-224.

12. Aimukhametova G, Ukybasova T, Hamidullina $\mathrm{Z}$, et al. The impact of maternal obesity on mother and neonatal health: A study in a tertiary hospital of Astana, Kazakhstan. Nagoya J Med Sci. 2012;74(1-2):83-92.

13. Voigt M, Straube S, Zygmunt M, Krafczyk B, Schneider K, Briese V. Obesity and pregnancy-a risk profile. Z Geburtshilfe Neonatol. 2008;212(6):201-205.

14. Adult Treatment Panel III. Third report of the National Cholesterol Education Program

This work is licensed under a Creative Commons Attribution 3.0 United States License.

This journal is published by the University Library System of the University of Pittsburgh as part of its D-Scribe Digital Publishing Program, and is cosponsored by the University of Pittsburgh Press. 
(NCEP) expert panel on detection, evaluation, and treatment of high blood cholesterol in adults (Adult Treatment Panel III) final report2002.

15. Arner P. Differences in lipolysis between human subcutaneous and omental adipose tissues. Ann Med. 1995;27:435-438.

16. Drake A, Reynolds R. Impact of maternal obesity on offspring obesity and cardiometabolic disease risk. Reproduction. 2010;140(3):387-398.

17. Watkins M, Rasmussen S, Honein M, Botto L, Moore C. Maternal obesity and risk for birth defects. Pediatrics. 2003;111(5 Pt 2):11521158 .

18. Blomberg M, Kallen B. Maternal obesity and morbid obesity: The risk for birth defects in the offspring. Birth Defects Res A Clin Mol Teratol. 2009;88(1):35-40.

19. Shaw G, Velie E, Schaffer D. Risk of neural tube defect-affected pregnancies among obese women. JAMA. 1996;275(14):1093-1096.

20. Werler M, Louik C, Shapiro S, Mitchell A. Prepregnant weight in relation to risk of neural tube defects. JAMA. 1996;275(14):1089-1092.

21. Rasmussen S, Chu S, Kim S, Schmid C, Lau J. Maternal obesity and risk of neural tube defects: A metaanalysis. Am J Obstet Gynecol. 2008;198(6):611-619.

22. Watkins M, Scanlon K, Mulinare J, Khoury M. Is maternal obesity a risk factor for anencephaly and spina bifida? Epidemiology. 1996;7(5):507-512.

23. Fraser A, Tilling $\mathrm{K}$, Macdonald-Wallis $\mathrm{C}$, et al. Association of maternal weight gain in pregnancy with offspring obesity and metabolic and vascular traits in childhood. Circulation. 2010;121(23):2557-2564.

24. Reynolds R, Allan K, Raja E, et al. Maternal obesity during pregnancy and premature mortality from cardiovascular event in adult offspring: Follow-up of 1,323,275 person years. BMJ. 2013;347:f4539.

25. Straughen J, Trudeau S, Misra V. Changes in adipose tissue distribution during pregnancy in overweight and obese compared with normal weight women. Nutr Diabetes. 2013;3:e84.
26. Roman H, Robillard $\mathrm{P}$, Hulsey $\mathrm{T}$, et al. Obstetrical and neonatal outcomes in obese women. West Indian Med J. 2007;56(5):421426.

27. Heslehurst N, Rankin J, Wilkinson J, Summerbell C. A nationally representative study of maternal obesity in England, UK: Trends in incidence and demographic inequalities in 619323 births, 1989-2007. Int J Obes (Lond). 2010;34(3):420-428.

28. Hedderson M, Williams M, Holt V, Weiss N, Ferrara A. Body mass index and weight gain prior to pregnancy and risk of gestational diabetes mellitus. Am J Obstet Gynecol. 2008;198(4):409.

29. Chu S, Callaghan W, Kim S, et al. Maternal obesity and risk of gestational diabetes mellitus. Diabetes Care. 2007;30(8):20702076.

30. Alanis M. Maternal super-obesity (body mass index $>$ or $=50$ ) and adverse pregnancy outcomes. Acta Obstet Gynecol Scand. 2010;89(7):924-930.

31. Cedergren M. Effects of gestational weight gain and body mass index on obstetric outcome in Sweden. Int $J$ Gynaecol Obstet. 2006;93(3):269-274.

32. Athukorala C, Rumbold A, Willson K, Crowther $\mathrm{C}$. The risk of adverse pregnancy outcomes in women who are overweight or obese. BMC Pregnancy Childbirth. 2010;10:56.

33. Mandal D, Manda S, Rakshi A, Dey R, Biswas S, Banerjee A. Maternal obesity and pregnancy outcome: A prospective analysis. $J$ Assoc Physicians India. 2011;59:486-489.

34. McIntyre H, Gibbons K, Flenady V, Callaway L. Overweight and obesity in Australian mothers: Epidemic or endemic? Med J Aust. 2012;196(3):184-188.

35. Kerrigan A, Kingdon C. Maternal obesity and pregnancy: A retrospective study. Midwifery. 2010;26(1):139-146.

36. Nucci L, Schmidt M, Duncan B, Fuchs S, Fleck E, Santos Britto M. Nutritional status of pregnant women: Prevalence and associated pregnancy outcomes. Rev Saude Publica. 2001;35(6):502-507.

This work is licensed under a Creative Commons Attribution 3.0 United States License.

This journal is published by the University Library System of the University of Pittsburgh as part of its D-Scribe Digital Publishing Program, and is cosponsored by the University of Pittsburgh Press. 
37. Abrams B, Parker J. Overweight and pregnancy complications. Int $J$ Obes. 1988;12(4):293-303.

38. Kumari A. Pregnancy outcome in women with morbid obesity. Int $J$ Gynaecol Obstet. 2001;73(2):101-107.

39. O'Brien T, Ray J, Chan W. Maternal body mass index and the risk of preeclampsia: A systematic overview. Epidemiology. 2003;14(3):368-374.

40. Usha Kiran T, Hemmadi S, Bethel J, Evans J. Outcome of pregnancy in a woman with an increased body mass index. BJOG. 2005;112(6):768-772.

41. Kristensen J, Vestergaard M, Wisborg K, Kesmodel U, Secher N. Pre-pregnancy weight and the risk of stillbirth and neonatal death. BJOG. 2005;112(4):403-408.

42. Nohr E, Bech B, Davies M, Frydenberg M, Henriksen T, Olsen J. Prepregnancy obesity and fetal death: A study within the Danish National Birth Cohort. Obstetrics and gynecology. 2005;106(2):250-259.

43. Tennant P, Rankin J, Bell R. Maternal body mass index and the risk of fetal and infant death: A cohort study from the North of England. Hum Reprod. 2011;26(6):1501-1511.

44. Conner S, Verticchio J, Tuuli M, Odibo A, Macones G, Cahill A. Maternal obesity and risk of postcesarean wound complications. $\mathrm{Am}$ J Perinatol. 2013.

45. Sheiner E, Levy A, Menes T, Silverberg D, Katz M, Mazor M. Maternal obesity as an independent risk factor for caesarean delivery. Paediatr Perinat Epidemiol. 2004;18(3):196201.

46. Ehrenberg H, Mercer B, Catalano P. The influence of obesity and diabetes on the prevalence of macrosomia. Am $J$ Obstet Gynecol. 2004;191(3):964-968.

47. Smith G, Shah I, Pell J, Crossley J, Dobbie R. Maternal obesity in early pregnancy and risk of spontaneous and elective preterm deliveries: A retrospective cohort study. Am J Public Health. 2007;97(1):157-162.

48. Weiss J, Malone F, Emig D, et al. Obesity, obstetric complications and cesarean delivery rate--a population-based screening study. Am $J$ Obstet Gynecol. 2004;190(4):1091-1097.

49. Metwally M, Ong K, Ledger W, Li T. Does high body mass index increase the risk of miscarriage after spontaneous and assisted conception? A meta-analysis of the evidence. Fertil Steril. 2008;90(3):714-726.

50. Leung $T$, Leung $T$, Sahota $D$, et al. Trends in maternal obesity and associated risks of adverse pregnancy outcomes in a population of Chinese women. BJOG. 2008;115(12):15291537.

51. Nohr E, Vaeth $M$, Bech $B$, Henriksen $T$, Cnattingius S, Olsen J. Maternal obesity and neonatal mortality according to subtypes of preterm birth. Obstetrics and gynecology. 2007;110(5):1083-1090.

52. Cnattingius $S$, Villamor E, Johansson $S$, et al. Maternal obesity and risk of preterm delivery. JAMA. 2013;309(22):2362-2370.

53. Kamanu C, Onwere S, Chigbu B, Aluka C, Okoro O, Obasi M. Fetal macrosomia in African women: A study of 249 cases. Arch Gynecol Obstet. 2009;279(6):857-861.

54. Bowers D, Cohen W. Obesity and related pregnancy complications in an inner-city clinic. J Perinatol. 1999;19(3):216-219.

55. Poston L, Harthoorn L, Van Der Beek E, Contributors to the ILSI Europe Workshop. Obesity in pregnancy: Implications for the mother and lifelong health of the child. A consensus statement. Pediatr Res. 2011;69(2):175-180.

56. Arrowsmith S, Wray S, Quenby S. Maternal obesity and labour complications following induction of labour in prolonged pregnancy. BJOG. 2011;118(5):578-588.

57. Tenenbaum-Gavish K, Hod M. Impact of maternal obesity on fetal health. Fetal Diagn Ther. 2013.

58. Koch L. Obesity: Effect of maternal obesity on neonatal outcomes. Nat Rev Endocrinol. 2013.

59. Higgins L, Mills T, Greenwood S, Cowley E, Sibley C, Jones R. Maternal obesity and its effect on placental cell turnover. J Matern Fetal Neonatal Med. 2013;26(8):783-788.

This work is licensed under a Creative Commons Attribution 3.0 United States License.

This journal is published by the University Library System of the University of Pittsburgh as part of its D-Scribe Digital Publishing Program, and is cosponsored by the University of Pittsburgh Press. 
60. Li R, Jewell S, Grummer-Strawn L. Maternal obesity and breast-feeding practices. Am J Clin Nutr. 2003;77:931-936.

61. Maasilta P, Bachour A, Teramo K, Polo O, Laitinen L. Sleep-related disordered breathing during pregnancy in obese women. Chest. 2001;120:1448-1454.

62. SPSS for Windows [computer program]. Version 15.0. Chicago: SPSS Inc.; Released 2006.

63. Fattah C, Farah N, Barry S, O'Connor N, Stuart B, Turner M. Maternal weight and body composition in the first trimester of pregnancy. Acta Obstet Gynecol Scand. 2010;89(7):952955.

64. Akter J, Shahjahan M, Hossain S, Chowdhury $\mathrm{H}$, Ali L. Prevalence and determinants of overweight and obesity among diabetic women of reproductive age attending a tertiary care hospital in Bangladesh.
65. Yogev Y, Langer O. Pregnancy outcome in obese and morbidly obese gestational diabetic women. Eur J Obstet Gynecol Reprod Biol. 2008;137(1):21-26.

66. Boseley S. More than one in 20 pregnant women severely obese. The Guardian. December 7, 2010, 2010.

67. Lashen H, Fear K, Sturdee DW. Obesity is associated with increased risk of first trimester and recurrent miscarriage: matched casecontrol study. Human reproduction (Oxford, England). Jul 2004;19(7):1644-1646.

68. Poston L. Maternal obesity, gestational weight gain and diet as determinants of offspring long term health. Best Pract Res Clin Endocrinol Metab. 2012;26(5):627-639.

This work is licensed under a Creative Commons Attribution 3.0 United States License.

This journal is published by the University Library System of the University of Pittsburgh as part of its D-Scribe Digital Publishing Program, and is cosponsored by the University of Pittsburgh Press. 
GoON

Table 1: Distribution of respondents by age and BMI level.

\begin{tabular}{|c|c|c|c|c|c|}
\hline Age & Total & $\begin{array}{l}\text { Under } \\
\text { weight }\end{array}$ & $\begin{array}{c}\text { Normal } \\
\text { (Healthy weight) }\end{array}$ & Overweight & Obesity \\
\hline & 426 & $25(5.9 \%)$ & $140(32.8 \%)$ & $171(40.1 \%)$ & $90(21.2 \%)$ \\
\hline$<20$ & $66(15.5 \%)$ & $25(100 \%)$ & $24(17.1 \%)$ & $10(5.8 \%)$ & $7(7.8 \%)$ \\
\hline $21-25$ & $114(26.8 \%)$ & 0 & $79(56.4 \%)$ & $23(13.5 \%)$ & $12(13.3 \%)$ \\
\hline $26-30$ & $108(25.4 \%)$ & 0 & $25(17.8 \%)$ & $56(32.7 \%)$ & $27(30 \%)$ \\
\hline$\geq 31$ & $138(32.3 \%)$ & 0 & $12(8.7 \%)$ & $82(48 \%)$ & $44(48.9 \%)$ \\
\hline
\end{tabular}

This work is licensed under a Creative Commons Attribution 3.0 United States License.

This journal is published by the University Library System of the University of Pittsburgh as part of its D-Scribe Digital Publishing Program and is cosponsored by the University of Pittsburgh Press. 
Table 2: Unadjusted OR for selected age ( $\geq 30)$ by BMI category.

\begin{tabular}{|c|c|c|c|c|}
\hline \multirow[t]{2}{*}{ Total } & \multicolumn{2}{|c|}{$\begin{array}{l}\text { Overweight } \\
\text { (BMI } 25-29.9 \mathrm{~kg} / \mathrm{m}^{2} \text { ) }\end{array}$} & \multicolumn{2}{|c|}{$\begin{array}{l}\text { Obese } \\
\left(\text { BMI }>30 \mathrm{~kg} / \mathrm{m}^{2}\right)\end{array}$} \\
\hline & & $\mathrm{OR}(95 \% \mathrm{CI})$ & & $\mathrm{OR}(95 \% \mathrm{CI})$ \\
\hline 261 & $\mathrm{n}=171$ & $3.3 ; 2.15-4.99$ & $\mathrm{n}=90$ & $2.5 ; 1.53-3.96$ \\
\hline
\end{tabular}

This work is licensed under a Creative Commons Attribution 3.0 United States License.

This journal is published by the University Library System of the University of Pittsburgh as part of its D-Scribe Digital Publishing Program and is cosponsored by the University of Pittsburgh Press. 
GoON

Table 3: Distribution of respondents according to the presence or absence of specific weight status.

\begin{tabular}{|c|c|c|c|c|c|c|}
\hline Character & $\begin{array}{l}\text { Present/ } \\
\text { absent }\end{array}$ & $<20$ years & $21-25$ & $26-30$ & $\geq 31$ & Statistical values \\
\hline \multirow[t]{2}{*}{ Obesity } & Present & $7(7.8 \%)$ & $12(13.3 \%)$ & $27(30 \%)$ & $44(48.9 \%)$ & \multirow[t]{2}{*}{$\mathrm{X}^{2}=14.18, p<0.05$} \\
\hline & Absent & $59(17.5 \%)$ & $102(30.4 \%)$ & $81(24.1 \%)$ & $94(28 \%)$ & \\
\hline \multirow[t]{2}{*}{ Overweight } & Present & $10(5.8 \%)$ & $23(13.5 \%)$ & $56(32.7 \%)$ & $82(48 \%)$ & \multirow[t]{2}{*}{$\mathrm{X}^{2}=31.58, p<0.05$} \\
\hline & Absent & $56(21.9 \%)$ & $91(35.7 \%)$ & $52(20.4 \%)$ & $56(22 \%)$ & \\
\hline \multirow[t]{2}{*}{ Normal weight } & Present & $24(17.1 \%)$ & $79(56.4 \%)$ & $25(17.9 \%)$ & $12(8.6 \%)$ & \multirow[t]{2}{*}{$\mathrm{X}^{2}=54.03, p<0.05$} \\
\hline & Absent & $42(14.7 \%)$ & $35(12.2 \%)$ & $83(29.0 \%)$ & $126(44.1 \%)$ & \\
\hline \multirow[t]{2}{*}{ Underweight } & Present & $25(100 \%)$ & 0 & 0 & 0 & \multirow[t]{2}{*}{$\mathrm{X}^{2}=12.73, p<0.05$} \\
\hline & Absent & 0 & $117(29.2 \%)$ & $108(26.9 \%)$ & $138(43.9 \%)$ & \\
\hline
\end{tabular}

This work is licensed under a Creative Commons Attribution 3.0 United States License.

This journal is published by the University Library System of the University of Pittsburgh as part of its D-Scribe Digital Publishing Program and is cosponsored by the University of Pittsburgh Press. 
Figure 1: Distribution of respondents by BMI level.

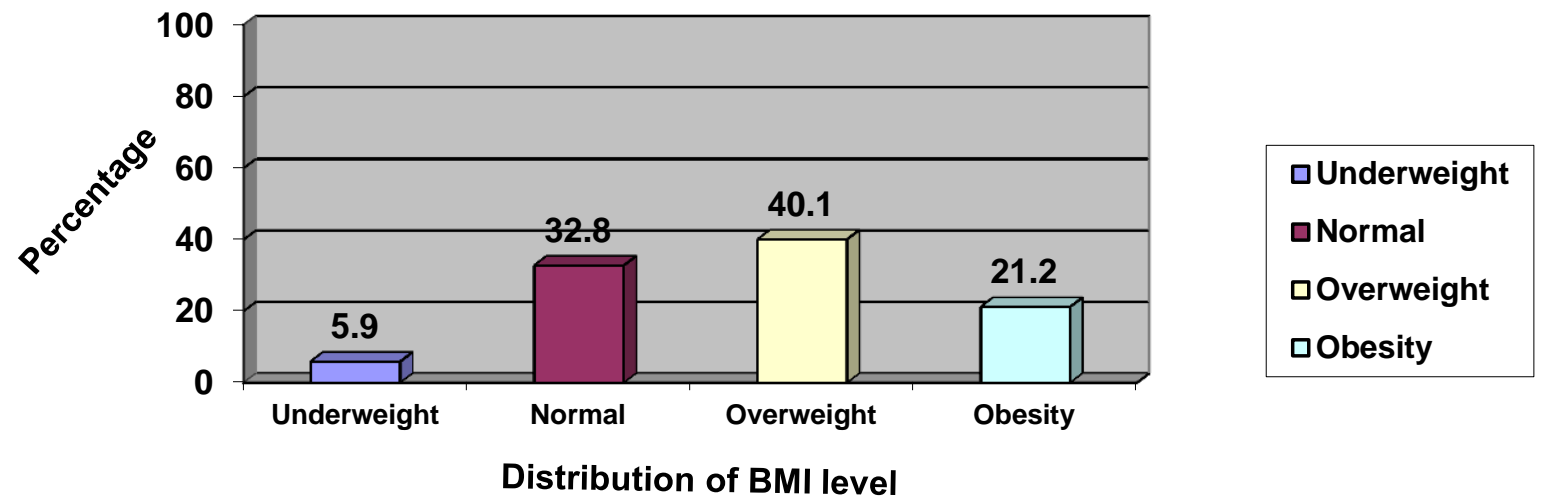

This work is licensed under a Creative Commons Attribution 3.0 United States License.

This journal is published by the University Library System of the University of Pittsburgh as part of its D-Scribe Digital Publishing Program, and is cosponsored by the University of Pittsburgh Press. 